\title{
1. International space law and its implications for outer space activities
}

The importance and potential of space activities have drawn the attention of the world community to intellectual property law's protection of such activities. To appreciate how and to what extent space activities should be protected, it is first necessary to analyze the principles set forth in space law instruments and find out how these legal rules are applied to space activities. This chapter begins with a categorization of space activities. The next part is devoted to defining and delimiting 'outer space' to provide a better understanding of the boundary to which this legal regime properly applies. Then, space law treaties will be briefly examined. The fundamental principles of space law (freedom of use and access, nonappropriation, the 'Province of all Mankind' and the 'Common Heritage of Mankind') will be shown to be based upon common, or shared, 'ownership' among states. These space law principles and basic principles of private intellectual property rights - which exclude others from exploiting the protected work without the right holder's consent - would appear to conflict, such that it would seem problematic to apply both legal regimes to intellectual works created in outer space. This problem will be discussed in more detail, together with an analysis of its implications to space activities, in the last part of this chapter.

\section{SPACE ACTIVITIES}

There are a number of activities that take place in outer space. Satellites are presently the dominant commercial activity in the spatial area. These satellites operate in various fields, such as telecommunication, navigation, remote sensing of the earth's resources and meteorology. ${ }^{22}$ Satellites are employed in either earth-oriented activities or space-related activities;

22 James J. Trimble, 'International Law of Outer Space and Its Effect on Commercial Space Activity’ (1984) 113 Pepperdine Law Review 521, 523. 
i.e., activities which are carried out in outer space but which directly affect the earth by capturing images of the earth or transmitting signals to the earth. Finally, space-created activities exploit space resources, for example, using Helium-3 available on the Moon as a component of nuclear power or producing cost-effective pharmaceuticals and electronics under zero gravity. ${ }^{23}$

\section{THE DEFINITION AND DELIMITATION OF OUTER SPACE}

At present, there is no precise definition of either 'outer space' or 'delimitation of outer space', and these two terms are used interchangeably. This book will use 'delimitation of outer space'. Although the delimitation question has long been discussed under the auspices of the Legal Sub-Committee of the Committee on the Peaceful Uses of Outer Space, a body of the United Nations since $1966,{ }^{24}$ no agreement has yet been reached. While there is no delimitation of outer space under any international regime, some states include definitions in their national legislation. For example, Australia amended its Space Activities Act of 1988 in 2002 to define 'outer space' as an area beyond the distance of $100 \mathrm{~km}$ above mean sea level. ${ }^{25}$

One important factor preventing agreement on the definition and delimitation of outer space is the lack of consensus on the criteria for setting such delimitation. Two main approaches, the 'spatial' approach and the 'functional' approach, have been put forward for consideration.

\subsection{The Spatial Approach}

Under the spatial approach, the boundary of outer space is based upon scientific and technical criteria. These, in turn, split into several theories, ${ }^{26}$ namely:

23 David Lamb, The Search for Extraterritorial Intelligence: A Philosophical Inquiry (Routledge 2001) 124.

24 UN DOC. A/AC.105/769 (18 January 2002) para 3.

25 UN DOC. A/AC.105/865/Add 11 (21 February 2012) p. 2.

26 UN. Doc. A/AC.105/C.2/7 (7 May 1970) and UN Doc A/AC/C.2/7/Add. 1 (21 January 1977). See more in I.H.Ph. Diederiks-Verschoor and V. Kopal, An Introduction to Space Law ( $3^{\text {rd }}$ ed., Wolters Kluwer 2008) 17-20; Marietta Benkö et al, Space Law in the United Nations (Martinus Nijhoff Publishers 1985) 127-130; Bin Cheng, Studies in International Space Law (Clarendon Press Oxford 1997) 444-451; and Rhys Monahan, 'The Sky's the Limit? Establishing 
A. Demarcation based upon an equation of the upper limit of national sovereignty with the concept of 'atmosphere';

B. Demarcation based upon the division of atmosphere into layers;

C. Demarcation based upon the maximum altitude of aircraft flight (theory of navigable air space);

D. Demarcation based upon aerodynamic characteristics of flight instrumentalities (von Karman line);

E. Demarcation according to the lowest perigee of an orbiting satellite; 27

F. Demarcation based upon the earth's gravitational effects;

G. Demarcation based upon effective control; and

H. Demarcation based upon the division of space into zones.

Of these, E - the lowest perigee of an orbiting satellite - has gained most attention from those states which favor a spatial delimitation. ${ }^{28}$ This theory suggests that a boundary be set at an altitude of approximately $100-110 \mathrm{~km}$ above sea level. ${ }^{29}$ This altitude is close to one that the USSR submitted in a working paper to the United Nations Committee on the Peaceful Uses of Outer Space (UNCOPUOS) Legal Sub-Committee for consideration during its 22nd session in $1983,{ }^{30}$ which proposed the boundary between air space and outer space at an altitude not exceeding $110 \mathrm{~km}$ above sea level.

\subsection{The Functional Approach}

Contrary to the spatial approach, the boundary adopted under the functional approach is based upon the nature, type and circumstances of various space activities. ${ }^{31}$ States favoring this approach suggest that a distinction be made between aeronautical and astronautical activities. Thus, activities are regulated in accordance with the particular mission

a Legal Delimitation of Airspace and Outer Space' (D.Phil thesis, Durham University 2008) 23-25 and 37-52.

27 The perigee is the point where the orbit is nearest to the earth while the apogee is farthest away from the earth. See Benkö (n 26) 124.

28 Ibid 127.

29 Ibid 128.

30 UN Doc. A/AC.105/C.2/L.139 (4 April 1983).

31 Benkö (n 26) 129; Diederiks-Verschoor and Kopal (n 26) 18. 
and objectives under a single legal regime of either air law or space law. ${ }^{32}$ Implicitly, there is no need to establish a delimitation of outer space. ${ }^{33}$

Those states which favor the precise demarcation of outer space support the spatial approach, whereas those who oppose to such demarcation prefer the functional approach, as the latter allows more flexibility in terms of the development of space technology. ${ }^{34}$

This lack of a definition and delimitation of outer space is problematic, since certain particular areas are neither explicitly defined as 'air space' or 'outer space'. For example, it is vague whether an area located between $80 \mathrm{~km}$ and $120 \mathrm{~km}$ above sea level would be classified as either air space or outer space in the absence of demarcation, since $80 \mathrm{~km}$ is the maximum attitude for convention aircraft, and $120 \mathrm{~km}$ is the lowest attitude in which space activities could be carried out. ${ }^{35}$ Satellites which are stationed in a geostationary orbit are a good example of this ambiguity. Owing to this lack of any internationally recognized delimitation, equatorial states claim sovereignty over that part of the geostationary orbit which is located over their respective territories; 36 whereas technologically developed countries believe that the geostationary orbit is an integral part of outer space. ${ }^{37}$ This uncertain status of areas leads to legal jurisdictional problems.

According to international law, a state has sovereignty over the airspace above its territory. ${ }^{38}$ However, national sovereignty does not extend into outer space. ${ }^{39}$ Thus, it is necessary to determine where a state's airspace ends to ensure that the appropriate legal regime is applied. One possible scenario which might occur and which is relevant to the subject of this book is the creation or infringement of an intellectual work is in just such an ambiguous location. This would cast doubt on the 'legal' location of creation or infringement, and the question of which applicable legal regime arises. Should we apply the law of the

32 Ibid.

33 Ibid.

34 Trimble (n 22) 556-557.

35 Diederiks-Verschoor and Kopal (n 26) 17.

36 The Bogota Declaration was issued on 3 December 1976 by the equatorial states, claiming their sovereignty over the geostationary orbit. The text of the Bogota declaration is available at <http://www.spacelaw.olemiss.edu/library/ space/International_Agreements/declarations/1976_bogota_declaration.pdf> (accessed 31 January 2016).

37 Diederiks-Verschoor and Kopal (n 26) 21 and Benkö (n 26) 138.

38 Article 1 of the 1944 Chicago Convention.

39 Article II of the Outer Space Treaty. 
underlying state or is there no law to apply? For example, would satellite signals transmitted from a satellite stationed in a geostationary orbit located over equatorial countries be considered as works created or, if intercepted, be infringed, in outer space or in the sovereign air space of those respective countries? These hypothetical examples highlight why a boundary is necessary if unpredictability arising from different legal application is to be avoided. While it might be argued that this issue is being overemphasized at this stage, given increasing use of space technology, this problem is worth considering now rather than later.

\section{AN OVERVIEW OF INTERNATIONAL SPACE LAW}

In the realm of international space law, there are now five treaties under the auspices of the United Nations. These are: the 1967 Treaty on Principles Governing the Activities of States in the Exploration and Use of Outer Space, including the Moon and Other Celestial Bodies (hereinafter referred to as 'the Outer Space Treaty'), the 1968 Agreement on the Rescue of Astronauts, the Return of Astronauts and the Return of Objects Launched into Outer Space ('the Rescue Agreement'), the 1972 Convention on International Liability for Damage Caused by Space Objects ('the Liability Convention'), the 1976 Convention on Registration of Objects Launched in Outer Space ('the Registration Convention') and the 1979 Agreement Governing the Activities of States on the Moon and Other Celestial Bodies ('the Moon Agreement'). Only the Outer Space Treaty and the Moon Agreement are relevant to this book, and so the main focus will be on these treaties. However, this chapter will touch upon the other three instruments briefly.

\subsection{The Outer Space Treaty of 1967}

The Outer Space Treaty is the first international instrument on space law. It established regulations for activities carried out in outer space and on celestial bodies. Other subsequent international agreements on outer space have been enacted mainly to amplify and explicate the rules embodied in the Outer Space Treaty. ${ }^{40}$ While there is no explicit provision on intellectual property rights in outer space in this treaty, this

$40 \quad$ Trimble (n 22) 528. 
does not render it irrelevant to this research, because it includes provisions which are relevant when considering the exploitation of intellectual property rights in this extraterritorial area. Only these relevant provisions will be discussed in this chapter.

Article I(1) of the Outer Space Treaty states that any exploitation and use of outer space must be carried out 'for the benefit and in the interest of all states irrespective of their economic and social capabilities and shall be the province of all mankind'. ${ }^{41}$ However, the treaty itself lacks either an explicit definition of the term 'province of all mankind' or any further explanation. ${ }^{42}$ The United States has interpreted this term as being equivalent to 'benefit of all mankind', which has led to a divergence of interpretations. ${ }^{43}$ We shall return to this later in the chapter. ${ }^{44}$

Article I(2) sets out a principle of freedom of exploration and use of outer space on the basis of equality and in accordance with international law. ${ }^{45}$ Article III of the treaty further provides that the space activities are carried out in accordance with the international law including the Charter of the United Nations. ${ }^{46}$

Article II establishes the 'non-appropriation principle' by stating that outer space is not subject to 'national appropriation ... by any means'. ${ }^{47}$ It is arguable whether private appropriation is allowed under this article, since the provision refers to national appropriation and does not explicitly mention private appropriation. However, most scholars are of the

41 Article I(1) of the Outer Space Treaty states, 'The exploration and use of outer space, including the Moon and other celestial bodies, shall be carried out for the benefit and in the interests of all countries, irrespective of their degree of economic or scientific development, and shall be the province of all mankind.'

42 Diederiks-Verschoor and Kopal (n 26) 25.

43 Treaty on Outer Space, Hearing before the Commission on Foreign Relations Senate Executive D. 90th Cong, 1st Session 56, 1967, 69-70.

44 See Section 5 of this chapter.

45 Article I(2) of the Outer Space Treaty states, 'Outer space, including the Moon and other celestial bodies, shall be free for exploration and use by all States without discrimination of any kind, on a basis of equality and in accordance with international law, and there shall be free access to all areas of celestial bodies'.

46 Article III of the Outer Space Treaty states, 'States Parties to the Treaty shall carry on activities in the exploration and use of outer space, including the Moon and other celestial bodies, in accordance with international law, including the Charter of the United Nations, in the interest of maintaining international peace and security and promoting international co-operation and understanding.'

47 Article II of the Outer Space Treaty states, 'Outer Space, including the Moon and other celestial bodies, is not subject to national appropriation by claim of sovereignty, by means of use or occupation, or by any other means'. 
view that the purpose of Article II's non-appropriation rule is to prevent any appropriation of outer space, irrespective of who is making the claim. ${ }^{48}$ In other words, this provision identifies the legal nature of outer space as res communis, in which all states are equally free to access, use or exploit, but all are prohibited from any kind of appropriation.

Article VIII of the treaty establishes jurisdiction for a state of registry 'to retain jurisdiction and control over such object, and over any personnel thereof, while in outer space or on a celestial body'. Such jurisdiction and control applies to personnel only and does not extend to any third party.

When the Outer Space Treaty was concluded, its drafters probably would not have considered the issue of intellectual property rights in outer space, perhaps because it seemed premature to discuss the issue at that time. However, it is questionable how the two fundamental principles of space law, i.e., the province of all mankind and non-appropriation principles, are to be accommodated when applied to intellectual property creations in space activities. Thus, it is worth examining whether these two principles would recognize the intellectual property rights in outer space. Accordingly, this issue will be discussed in detail later in this chapter, ${ }^{49}$ together with a related 'common heritage of mankind' principle, which was established in the Moon Agreement. ${ }^{50}$

\subsection{The Rescue Agreement of 1968}

The Rescue Agreement sets forth the obligations for States Parties on assistance to astronauts in case of an accident, distress or emergency, including those practical measures for rescuing and assisting the crew. ${ }^{51}$ In addition, States Parties are bound to notify the launching authority and the Secretary-General of the United Nations immediately about any such relevant situation. ${ }^{52}$ This Agreement is not pertinent to the subject of this book.

48 Fabio Tronchetti, The Exploitation of Natural Resources of the Moon and Other Celestial Bodies (Martinus Nijhoff 2009) 29-33.

49 See Sections 4.2, 4.3 and 5.0 of this chapter.

50 Article 11 paragraph 1 of the Moon Agreement.

51 See more in Diederiks-Verschoor and Kopal (n 26) 31-34 and Bin Cheng (n 26) 263-285

52 Article 1 of the Agreement. 


\subsection{The Liability Convention of 1972}

The Liability Convention establishes liability principles for any damage caused by space objects and measures of compensation for victims of such damage. Pursuant to Article I of this Convention, four States potentially qualify as the 'launching State', which is defined as: (1) the state which launches; (2) the state which procures the launching; (3) the state whose territory is used for launching; and (4) the state whose facilities are used for launching. ${ }^{53}$ Victims have flexibility to obtain compensation from one of these four launching states for damage caused by a space object. ${ }^{54}$ Reference to the concept of 'launching state' will be discussed, where relevant, in following chapters. ${ }^{55}$

\subsection{The Registration Convention of 1976}

The purpose of the Registration Convention is to establish an identification system for objects launched into outer space. Specified information must be furnished to be recorded on a UN register in each case. ${ }^{56}$ Unlike registration of an aircraft or ship, registration of a space object does not automatically confer the nationality of the registering state on that object. ${ }^{57}$ This Convention is therefore only relevant to this book insofar as it is necessary to identify the state of registry when dealing with jurisdiction and choice-of-law matters, as discussed in Chapter 5.58 The Convention is silent on the issue of jurisdiction and control over unregistered space objects. ${ }^{59}$

\subsection{The Moon Agreement of 1979}

The Moon Agreement includes provisions which are pertinent for our study. In compliance with the Outer Space Treaty, Article 4 of the Moon

53 The 'launching authority' has been addressed in Article 6 of the Astronaut Agreement as the State responsible for the launching. The meaning of such authority has been made clearer by giving definition of 'launching State' in Article I (c) of this Convention.

54 Article II of the Convention, see more explanation about this Convention in Diederiks-Verschoor and Kopal (n 26) 35-44 and Cheng (n 26) 286-356.

55 See Chapter 3, Section 4 on infringement.

56 Article IV of the Convention.

57 This issue will be examined again in section 1.2.4 in Chapter 5.

58 See Chapter 5, the hypothetical cases number 1 and 3 under the choice of law section.

59 Diederiks-Verschoor and Kopal (n 26) 46. 
Agreement requires that 'the exploration and use of the Moon shall be the province of all mankind and shall be carried out for the benefit and in the interest of all countries, irrespective of their degree of economic or scientific development' ${ }^{60}$ This provision restates the province of all mankind principle, as contained in the Outer Space Treaty. Thus, the exploitation and the use of outer space, including the Moon and other celestial bodies, must be carried out for the benefit of all countries.

The Moon Agreement reaffirms the non-appropriation principle, as stated in the Outer Space Treaty. This is established in Article 11(2) of the Moon Agreement and further elaborated in Article 11(3) of this Agreement. In addition, Article 11(4) confirms the right to exploit and use the Moon on the basis of equality without any kind of discrimination. The discussion of these provisions will be examined later in this chapter, in Section 4.3.61

\section{FUNDAMENTAL PRINCIPLES OF INTERNATIONAL SPACE LAW}

\subsection{Freedom of Exploration and Use of Outer Space}

The doctrine of freedom of exploration and use of outer space, set out in the Outer Space Treaty, establishes the legal status of outer space as res communis: an area which is not subject to any claim by any state; a characteristic which outer space shares with the high sea. ${ }^{62}$ Article I(2) of the Outer Space Treaty embodies three basic rights: the right of free access, the right of free exploration and the right of free use. ${ }^{63}$ Thus, every state has an equal right to explore, use and access outer space and its resources, provided that such exploration and use are carried out for the benefit and in the interest of all countries, as required by Article I(1). However, the Treaty itself contains no further explanation of the meaning of these rights or the proviso. The provision of Article I(1) could be interpreted to mean that all countries not only have the right to take part in these activities, but also to enjoy a right of access to those technologies involved. Some scholars view the obligation (that all exploration and

\footnotetext{
60 Article I of Outer Space Treaty.

61 See below, Section 4.3.

62 Article 2 of the Geneva Convention on the High Seas and Article 89 of the 1982 Convention on the Law of the Sea and outer space (see UN General Assembly Resolutions 1962 (XVII), 1721 (XVI), and 1884 (XVIII).

63 Article I(2) of the Outer Space Treaty (n 45).
} 
use be carried out for the benefit and in the interest of all countries) as a general provision which sets a guideline for any space-faring nation in conducting their activities in outer space. ${ }^{64}$ Such an interpretation of this provision would enable a state or private entity to enjoy the fruit arising from its activities in outer space, including any intellectual property rights. In my opinion, it would be an overly broad interpretation of Article I of the Outer Space Treaty to require all benefits, including intellectual property rights, arising from any space venture to be relinquished.

Rather, this Article merely affirms the freedom of access and use of outer space, as long as such activities do not hamper or prevent others from likewise freely accessing and exploiting outer space. Applying this interpretation, any party is entitled to reap any benefit from any valueadded intellectual work created in outer space. Hence, enjoyment of a proprietary interest in technology of space activities is not in conflict with the principles enunciated in Article I of the Outer Space Treaty.

\subsection{Non-appropriation of Outer Space}

The non-appropriation principle was originally included in UN General Assembly Resolutions 1721 and its declaration of 1962, before later becoming legally binding by its incorporation as Article II of the Outer Space Treaty. ${ }^{65}$ The principle of non-appropriation in Article II of this Treaty confirms outer space as a res communis. ${ }^{66}$ It has been agreed that the aim of this Article is to ban any claim of national sovereignty or exclusive property rights in outer space and its celestial bodies. ${ }^{67}$ Articles 11(2) and 11(3) of the Moon Agreement reaffirm the non-appropriation

64 Trimble (n 22) 530 and Roger K. Hoover, 'Law and Security in Outer Space from the Viewpoint of Private Industry' (1983) 11 Journal of Space Law $115,122$.

65 The UN General Resolution 1721 (XVI) (20 December 1961) namely 'International Cooperation in the Peaceful Uses of Outer Space' and UN Declaration 1962 (XIII) (13 December 1963) namely 'Declaration Of Legal Principles Governing the Activities of States in the Exploration and Use of Outer Space.' The text of these two documents are available online at <http:// www.oosa.unvienna.org/oosa/SpaceLaw/gares/html/gares_16_1721.html> and <http://www.unoosa.org/oosa/SpaceLaw/lpos.html>, respectively (accessed 31 January 2016).

66 Glen Reynolds and Robert Merges, Outer Space Problems of Law and Policy (2nd ed., Westview Press 1997) 78.

67 Ibid. 
of the Moon and the prohibition of the property rights in the Moon, respectively. 68

Questions arise as to the exact meaning of this non-appropriation principle and whether it is possible for states to exploit and explore outer space without violating it. Does the non-appropriation principle mean that states and private entities are prevented from reaping the fruit resulting from their effort and investment in outer space? Since the drafters of the Outer Space Treaty chose to declare outer space res communis, ${ }^{69}$ rather than a res nullius,${ }^{70}$ the non-appropriation principle has to be read and interpreted in conjunction with the freedom of the exploration and exploitation principle set out in Article I of the treaty. ${ }^{71}$ Thus, one possible conclusion is that states and natural or legal persons are entitled to free and equal access to the environment of space which is in the interest of all countries, but in doing so, no assertion on any claim of ownership over these extraterritorial areas is permitted. ${ }^{72}$ However, some scholars view the term "national appropriation" in Article II as referring only to states, such that private appropriation is not forbidden. ${ }^{73}$

It would seem overly broad to interpret Article II as an absolute bar to property rights in natural resources in outer space. Taking into consideration the language of Article 6(2) of the Moon Agreement, which allows states to collect and remove samples of Moon minerals and substances, it appears that property rights over natural resources on the Moon is permissible, even only for a scientific purpose as stated in this provision. ${ }^{74}$ In addition, Article 11(3) of the Moon Agreement states that

\footnotetext{
68 Article 11(2) and Article 11(3) of the Moon Agreement.

69 A territory that is not subject to national appropriation in Bin Cheng (n 26) 80.

70 A territory that is not subject to the territorial jurisdiction of any recognized subject of international law but susceptible of national appropriation, ibid 80.

71 Glen Reynolds and Robert Merges (n 66) 80.

72 Leslie Tennen, 'Towards a New Regime for Exploration of Outer Space Mineral Resources' (2010) 88 Nebraska Law Review 794, 807; Fabio Tronchetti, 'The Non-Appropriation Principles as a Structural Norm of International Law: A New Way of Interpreting Article II of the Outer Space Treaty' (2008) 33 Air and Space Law 277, 280.

73 Tronchetti (n 72) 280-281 and Daniel A. Porras, 'Comment: The "Common Heritage” of Outer Space: Equal Benefits for Most of Mankind' (2006) 37 California Western International Law Journal 143, 154.

${ }_{74}$ Article 6(2) of the Moon Agreement provides: 'In carrying out scientific investigations and in furtherance of the provisions of this Agreement, the States Parties shall have the right to collect and remove from the Moon samples of its
} 
'Neither surface nor the substance of the Moon, nor any part thereof or natural resources in place, shall become property of any state'. This text leads some scholars to interpret that provision as allowing some acquisition of property from the Moon, since the Article only prohibits the acquisition of that which is 'in place'. This might permit appropriation of that which has already been removed from its place. ${ }^{75}$ But, one might also argue that since most space-faring nations have yet to ratify the Moon Agreement, its provisions cannot stand as a legal norm for the world community. ${ }^{76}$ Therefore, the non-appropriative nature of outer space which prohibits the acquisition of outer space from both public and private entities is still well-founded as a legal norm.

Some experts have suggested that the non-appropriation principle should be abrogated because it is considered an obstruction to the commercialization of outer space. ${ }^{77}$ However, the majority of states believe otherwise.

As the non-appropriation principle aims to prevent the acquisition of any part of outer space or its resources, it may be concluded that this rule is only designed to govern tangible property, not intangible property. This view has gained support from some scholars. ${ }^{78}$ This is because recognizing intellectual property rights in outer space or in works created in outer space would not result in physical appropriation either of parts of outer space or its resources. In addition, the past practice of some states to recognize intellectual property rights in works created in outer space supports the view that intellectual property rights in such works is possible and is justified. ${ }^{79}$

mineral and other substances. Such samples shall remain at the disposal of those States Parties which caused them to be collected and may be used by them for scientific purposes'.

75 Kemal Baslar, The Concept of the Common Heritage of Mankind in International Law (Martinus Nijhoff 1998) 167-169.

76 The United States, the USSR, and China are not parties to the Moon Agreement. For the status of the international agreements relating to outer space activities as of 8 April 2015 see UN doc A/AC.105/C.2/2015/CRP.8 available online at <http://www.unoosa.org/pdf/limited/c2/AC105_C2_2015_CRP08E.pdf> (accessed 29 December 2015).

77 Tennen (n 72) 807-809.

78 Christopher Miles, 'Assessing the Need for an International Patent Regime for Inventions in Outer Space' (2008) 11 Tulane Journal of Technology and Intellectual Property 59, 64.

79 For example, the US Patent in Space Act. 
However, the situation might be more complex if an intellectual property work created involved using outer space resources as a component of its output. Take, as a hypothetical example: Scientist A, a national of the United States, discovers a process to produce nuclear power using Helium-3 as its major constituent. Helium-3 is known to be a valuable resource for generating nuclear power which is rare on earth, but abundant on the Moon. ${ }^{80}$ The production of nuclear power using this process would be cost-effective if produced in outer space. But would the process of producing this nuclear power violate the non-appropriation principle if the Moon's natural resources are taken as part of this process? A strict interpretation would see use of Helium-3 as a type of appropriation of the Moon's resources, and so a breach of the nonappropriation obligation. But, if neither the production of such nuclear power nor intellectual property rights protecting the process are allowed, the world community would lose the benefit of this additional source of power. However, a compromise could be put forward which would allow exploitation of this intellectual property work based upon licensing. Any such licensing scheme would need to ensure third parties fair and equitable access to this process in order to uphold the principle of freedom of exploration and use, but with appropriate safeguards in place, exploitation via licensing would guarantee Scientist A an opportunity to enjoy some benefit from his effort and investment.

The situation is essentially the same when considering application of the non-appropriation principle to remote sensing and satellite telecommunication. This is because situating a satellite in orbit within a specific spatial area could be considered as an appropriation of outer space, particularly when taking into account the fact that geostationary orbits are considered a 'limited natural resource', and access to such resources must comply with the International Telecommunication Union (ITU) Constitution. ${ }^{81}$

80 Shameem Kazmi, 'Moon Mining: Myth or Reality?' Earth Times (27 September 2012) <http://www.earthtimes.org/energy/moon-mining-myh-reality/ 2201/> (accessed 31 January 2016).

81 Article 44(2) of the ITU Constitution which stipulates that 'In using frequency bands for radio services, Members shall bear in mind that radio frequencies and the geostationary-satellite orbit are limited natural resources and that they must be used rationally, efficiently and economically, in conformity with the provisions of the Radio Regulations, so that countries or groups of countries may have equitable access to both, taking into account the special needs of the developing countries and the geographical situation of particular countries' (emphasis added). The full text of the ITU Constitution is available 
However, pharmaceuticals and electronics produced under zero gravity should not be considered as a violation of the non-appropriation principle because those works are only created in outer space, without physically taking any space resources.

\subsection{The Province of All Mankind and Common Heritage of Mankind}

The 'province of all mankind' principle in the Outer Space Treaty (hereafter 'the Province principle') and the 'common heritage of mankind' principle in the Moon Agreement (hereafter 'the Common Heritage principle') both guarantee that outer space and its resources are a common heritage. However, they differ since the Province principle grants all states freedom of access to natural resources in outer space and its celestial bodies on an equal basis, whereas the Common Heritage principle, while providing for equal freedom of access, also requires the exploiter to share any benefit with all states. ${ }^{82}$ These two principles are the most controversial principles in space law, and no agreement has been reached as to their precise definition.

What is the implication of these two principles for intellectual property rights? Firstly, it is significant that the Outer Space Treaty, which establishes the Province principle, has been ratified by 102 states, whereas the Moon Agreement, which establishes the Common Heritage principle, has only 15 states parties, and these do not include the main space power countries: the United States, Russian Federation and China. ${ }^{83}$ Thus, the Province principle is more widely accepted than the Common Heritage principle. However, this does not mean that the Common Heritage principle gains less attention within the space law world community. A significant quantity of legal scholarship is devoted to the dominant role which the Common Heritage principle plays in space activities. ${ }^{84}$ Thus, it is appropriate to take account of the Common

online at <http://www.itu.int/dms_pub/itu-s/oth/02/09/s02090000115201pdfe. pdf $>$ (accessed 31 January 2016).

82 David Tan, 'Towards a New Regime for the Protection of Outer Space as the "province of all mankind"' (2000) 25 Yale Journal of International Law 145, 161.

83 The current status of the treaties as of 29 December 2015 is available online at <http://www.unoosa.org/pdf/limited/c2/AC105_C2_2015_CRP08E.pdf> (accessed 29 December 2015).

84 Tan (n 82) 161; Tronchetti (n 48); Baslar (n 75); Carl Q. Christol, 'The Common Heritage of Mankind Provision in the 1979 Agreement Governing the Activities of States on the Moon and Other Celestial Bodies' (1980) 14 International Lawyer 429; Rudiger Wolfrum, 'The Principle of the Common 
Heritage principle when considering the international law implications of any utilization of outer space and space resources, including the Moon.

Since neither the Outer Space Treaty nor the Moon Agreement include precise definitions of these principles, it is necessary to look at the texts of these treaties to obtain guidance for the proper interpretation of these principles.

Article I(I) of the Outer Space Treaty provides that 'the exploration and use of outer space ... shall be carried out for the benefit and in the interest of all countries, irrespective of their degree of economic or scientific development, and shall be the province of all mankind', and Article I(II) states that 'Outer Space, including the Moon and other celestial bodies, shall be free for exploration and use by all states ... and shall be free access to all areas of celestial bodies'.

Taking the requirements of Article I(I) and I(II) together, the Province principle as established in Article I(I) proclaims outer space as res communis, where all States can freely and equally access its resources regardless of their technological capability and contribution to the exploitation. ${ }^{85}$ The use of outer space resources is allowed as long as it does not interfere with others' uses. ${ }^{86}$ In addition, the res communis doctrine forbids states from claiming sovereignty and property rights over this common area and its parts, a doctrine which is also embodied as the non-appropriation principle in Article II of the treaty. ${ }^{87}$

Nevertheless, some scholars believe that the Province principle in Article I(I) of the Outer Space Treaty is not intended to be legally binding, but rather imposes only a moral obligation upon states. ${ }^{88}$ The

Heritage of Mankind' (1983) Max-Planck-Institut für ausländisches öffentliches Recht und Völkerrecht 312 available online at <http://www.zaoerv.de/43_1983/ 43_1983_2_a_312_337.pdf> (accessed 31 January 2016). Also, Scott Ervin, 'Law in a Vacuum: The Common Heritage Doctrine in Outer Space Law' (1984) 7 Boston College International and Comparative Law Review 403; Edward Guntrip, 'The Common Heritage of Mankind: An Adequate Regime for Managing the Deep Seabed?' (2003) 4 Melbourne Journal of International Law, 376; John Adolph, 'The Recent Boom in Private Space Development and the Necessity of an International Framework Embracing Private Property Rights to Encourage Investment' (2006) 40 International Lawyer 961.

85 Tronchetti (n 48) 23, see also Scott J. Shackelford, 'The Tragedy of the Common Heritage of Mankind' (2008) 27 Stanford Environmental Law Journal $101,110$.

86 Shackelford (n 85) 107.

87 Tronchetti (n 48) 87.

88 Opinions cited in Tronchetti (n 48) 24. 
basis of this position is explained on the grounds that Article I(I) neither elaborates how the exploration of outer space for the benefit of all States is to take place, nor how the benefits arising from space activities are to be shared. ${ }^{89}$ On the other hand, other scholars regard the Province principle of Article I(I) of the Outer Space Treaty as customary law binding all States..$^{90}$ This school refers to legal documents which preceded the treaty, namely the UN General Assembly Resolution 1721 and 1962 Declaration, to support their conclusion. ${ }^{91}$ These documents, which were finally translated into Article I(I) of the Outer Space Treaty, recognize the common interest of all mankind and express a desire that states should have legal binding principles governing space activities. ${ }^{92}$

Reference to a 'common heritage of mankind' principle, such as that in the Moon Agreement, has been employed elsewhere in international law in relation to the high seas and Antarctica. Like outer space, these areas are beyond national jurisdiction, and they are also enriched with valuable resources which are held non-appropriable by states.93 A "common heritage of mankind' principle was first put forward in 1910 when it was suggested that Antarctica should be an area commonly owned by all nations. ${ }^{94}$ It was later formally introduced to the world community in 1967, when United Nations Ambassador Arvid Pardo suggested that the seabed and oceans, being areas beyond any national jurisdiction, should be considered as a common heritage of mankind to be administered by an international authority for the benefit of all people. ${ }^{95}$ This principle was later embodied in Articles 11(1) of the Moon Agreement and in the Law of the Sea Convention of 1982.96

As mentioned above, the Common Heritage principle of the Moon Agreement shares some common characteristic with the Province principle in term of free access on an equal basis, but differs from the latter in some aspects. ${ }^{97}$ The Common Heritage principle has been interpreted

89 Ibid.

90 Ibid.

91 See UN documents cited above (n 65).

92 Tronchetti (n 48) 24.

93 Tronchetti (n 48) 86; Carl Q. Christol, The Modern International Law of

Outer Space (2nd ed., Pergamon Press 1984) 286; Wolfrum (n 84) 313.

94 Tronchetti (n 48) 91.

95 Ibid 92-93.

96 Article 11.1 of the Moon Agreement states, 'The Moon and its natural resources are the common heritage of mankind, which finds its expression in the provisions of this Agreement, in particular in paragraph 5 of this Article.'

97 Tan (n 82) 161. For more details on this issue, see, Tronchetti (n 48); Baslar (n 75); Christol, et al. (n 84). 
to mean that the protected areas and their natural resources form a human heritage, such that the interest of future generation must be taken into account when these common areas are being exploited. ${ }^{98}$ It prohibits any one state or person from exclusively using these areas or their resources. Thus a sharing of benefit arises from exploitative activities in these protected areas, in accordance with principles and rules established by an international regime. 99

The concept of equitable sharing of benefits through an international regime has been addressed in Articles 11(5) and 11(7) (d) of the Moon Agreement. ${ }^{100}$ The concept of benefit sharing comes from the belief that natural resources should be held in trust by all mankind. ${ }^{101}$

The Common Heritage principle has been interpreted differently among states. Developing states tend to hold that since common areas belong to 'all nations', any benefit derived from exploitation of such common resource should be shared equally among states, regardless of their respective contribution to the particular exploitation. ${ }^{102}$ Under this interpretation, nations would derive benefit from exploitative activities without making either a financial or intellectual investment. On the other hand, developed countries consider reference to equitable sharing extends only to mean that every state has an equal right to exploit natural

98 Tronchetti (n 48) 88.

99 Ibid.

100 Article 11(5) states that 'States Parties to this Agreement hereby undertake to establish an international regime, including appropriate procedures, to govern the exploitation of the natural resources of the Moon as such exploitation is about to become feasible. This provision shall be implemented in accordance with article 18 of this Agreement.'

Article 11(7) states:

The main purposes of the international regime to be established shall include:

(d) an equitable sharing by all States Parties in the benefits derived from those resources, whereby the interests and needs of the developing countries as well as the efforts of those countries which have contributed either directly or indirectly to the exploration of the Moon, shall be given special consideration.

101 Baslar ( $n$ 75) 172. It should be noted that this concept of benefit sharing is comparable to the access and benefit sharing (ABS) regime in the Convention on Biological Diversity (CBD). Article $8(\mathrm{j})$ of the Convention establishes ABS regime requiring that the use of genetic resources be treated on a fair and equitable basis.

102 Ibid 165. 
resources freely, such that states have no legitimate claim to the technology or investment in other's exploitation. ${ }^{103}$

It is noted that a provision in the Moon Agreement which establishes an international 'policing' regime is ambiguous in terms of its implementation. While the Convention on the Law of the Sea ('UNCLOS') of 1982 includes the same provision, ${ }^{104}$ pursuant to part XI of the UNCLOS, an International Seabed Authority has been set up with its clear authorization for the management of the exploration and exploitation of the deep seabed. ${ }^{105}$ In contrast, while Article 11(5) of the Moon Agreement requires States Parties to set up an international regime to oversee utilization of the Moon, the treaty does not directly establish such entity itself. In addition, this provision does not seem to be compulsory as it relies upon the good faith of States Parties to establish such an entity. Moreover, the Moon Agreement does not provide any direction for how to equitably share the benefits and what exactly such 'benefits' mean. ${ }^{106}$ Taking into account the lack of clear guidance in the Moon Agreement itself, and the divergent interpretation of equitable sharing concept among states, it is questionable how the Common Heritage principle set out in the Moon Agreement should be implemented. However, it is likely that the interpretation of the non-space power nations might prevail based on the fact the space power countries are all reluctant to ratify the Moon Agreement.

Additionally, the Common Heritage principle is limited to the Moon, its resources and other celestial bodies within the solar system; it does not govern outer space more generally. ${ }^{107}$ In other words, except for the Moon (its resources and other celestial bodies), outer space (and its resources) is subject only to the Province principle which does not oblige states to share the benefit through the international authority, as specified in the Common Heritage principle.

Another pertinent point is Article 4 of the Moon Agreement, which states that: "The exploration and use of the Moon shall be the province of all mankind and shall be carried out for the benefit and in the interests of all countries, irrespective of their degree of economic or scientific

103 Carol R. Buxton, 'Property in Outer Space: The Common Heritage of Mankind Principles vs. The "first in time, first in right, rule of property law", (2004) 69 Journal of Air Law and Commerce 689, 692-693.

104 Tronchetti (n 48) 54.

105 Part XI Section 4 of the UNCLOS.

106 Tronchetti (n 48) 55 and Shackelford (n 85) 137.

107 Articles 1.1 and 11.1 of the Moon Agreement. 
development'. So, whereas Article 11(1) of the Moon Agreement identifies the Moon and its natural resources as the 'common heritage of mankind', Article 4 of the same treaty refers to the 'province of all mankind'.

While some scholars therefore view 'province of all mankind' and 'common heritage of mankind' as equivalent and interchangeable terms, ${ }^{108}$ I conclude otherwise. If the two terms were equivalent, why would a single instrument, the Moon Agreement, feature two different terms in the different provisions, rather than consistently adopting a single term? My view is supported by the fact that the two terms are not contradictory and can be interpreted in a consistent way: the Moon Agreement recognizes the legal status of the Moon and its resources as a common heritage of mankind (Article 11(1)) and provides that the method of management for the exploration and use of the Moon must be in line with the province of all mankind principle (Article 4). In other words, the 'common heritage of mankind' principle is an extension of the 'province of all mankind' principle, which further requires an equitable sharing benefit and establishment of a legal regime to regulate exploitation of the Moon.

Thus, it is reasonable to conclude that an intellectual output resulting from outer space activities may be protected, and that only the contributing states can reap the fruit of their investment. In addition, application of the Province and Common Heritage principles are consistent with the exclusive private rights arising from intellectual property protection regimes. 109

Since the Province and Common Heritage principles share common characteristics (the latter requiring an additional equitable sharing of benefit), analysis of their implications to space activities in term of intellectual property rights will be addressed concurrently.

108 Bess C.M. Reijnen, The United Nations Space Treaties Analysed (Editions Frontieres 1992) 96; Yun Zhao, Space Commercialization and the Development of Space Law from a Chinese Legal Perspective (Nova Science 2009) 6.

109 See conclusion chapter (Q 1). 


\section{THE APPLICATION OF THE PROVINCE OF ALL MANKIND AND THE COMMON HERITAGE OF MANKIND PRINCIPLES TO OUTER SPACE ACTIVITIES}

For the purpose of my analysis, it is appropriate to divide space activities into three groups, namely: (1) space-created works, the production of which involves use of outer space resources. Generating nuclear power using Helium-3 and manufacturing pharmaceuticals or electronics under zero gravity fall under this category; (2) space-related activities i.e., activities conducted in outer space but which are functionally related to earth, e.g., remote sensing and satellite telecommunication; and (3) non space-related works i.e., any work created in outer space which does not fall in either of the other two categories.

Are all three categories subject to the Common Heritage principle? Are those entities engaging in these space activities required to share any benefit derived from their investment? Do the Province and Common Heritage of Mankind principles override any intellectual property rights of those engaging in space activity? To answer these questions, we need to review the treaties where these two principles appear to find out how these two principles are interpreted. To recap, Article I of the Outer Space Treaty and Article 4(1) of the Moon Agreement state: 'the exploration and use of outer space shall be the province of all mankind', and Article 11(1) of the Moon Agreement further provides that 'the Moon and its natural resources are the common heritage of mankind'. These provisions define the legal status of outer space and its resources as a common heritage of mankind, which no public or private entity can appropriate as their own.

Since the Common Heritage and the Province principles are enunciated to govern the use, exploration and exploitation of outer space and its resources, an essential first step is to interpret the terms 'use', 'exploration' and 'exploitation'.

The term 'use' is considered to be equivalent to 'utilization' and 'exploitation', with the proviso that 'exploitation' seems to involve a commercial characteristic. ${ }^{110}$ In addition, taking account of views expressed during negotiations relating to the draft treaty and states' practice prior to and after entry into force of the treaty, it could be concluded that

\footnotetext{
110 Reijnen (n 108) 93.
} 
the terms 'use', 'exploration' and 'exploitation' encompass non-exclusive rights of all states to engage in exploitative activities. ${ }^{111}$

Applying this now to the three categories of outer space activities, processing Helium-3 available on the Moon to produce nuclear power can be better justified as 'using' the Moon and its resources, rather than being construed as being a space-created product. This is because the exemplar clearly acquires physical resources from the Moon as part of its process, rather than just taking advantage of weightlessness conditions on the Moon for processing. Furthermore, taking into consideration the potential breath of scope, as indicated above, it is possible that the production of such space-created products under weightlessness conditions may also be determined as falling within the scope of 'use, exploration and exploitation' of outer space, since these products are a result and benefit from space-exploitative activity. The space-related works, remote sensing and satellite telecommunication, might also 'use' outer space resources if applying the same interpretation of 'using', since these satellites have to be stationed in the orbit for their operations. On the other hand, intellectual works created while in outer space, but without any involvement of space resources - for example, writing new software code or a literary work - should fall outside the scope of the principles under consideration.

The next questions are how and to what extent the Province and Common Heritage principles apply to these space-related and spacecreated activities conducted 'using' space resources and the zero-gravity advantage, and then to consider the intellectual property law implications. In particular, does application of these principles mean that right holders have to relinquish their intellectual property rights by sharing the benefit with others, who have not contributed labor and effort in creation of such works?

I shall first consider remote sensing data. In a typical scenario, the state which is being monitored lacks the technological capability necessary to access any raw data and so would have to purchase processed data about its own territory from the state responsible for the remote sensing activity. Is this requirement to purchase contrary to the Province and Common Heritage principles? Does freedom to access, freedom of use and an equitable sharing mean of space law require the 'sensing' state to provide free use, access and sharing of all remote sensing data in a non-commercial way?

\footnotetext{
111 Christol (n 93) 42.
} 
In order to answer these questions, it is necessary to supplement the texts of the space treaties guidance provided in UN Resolution 41/65 on the topic of remote sensing. ${ }^{112}$ Although the resolution has no legal force, it has influential weight for possible future legislation. ${ }^{113}$ Principle IV of this resolution reaffirms that the remote sensing activities 'shall be conducted in accordance with the principles contained in article I of the Outer Space Treaty' and that such 'activities shall be conducted on the basis of respect for the principle of full and permanent sovereignty of all states and people over their own wealth and natural resources'. Taking this UN principle into account, together with the Outer Space Treaty, one scholar concludes that the commercial practice of selling remote sensing data falls outside the common interests, since the sensed state has to pay for data concerning its own territory. ${ }^{114}$

However, in my view, it would be incorrect to interpret that a free access, free use and an equal sharing of information requirement on remote sensing data has to be on non-commercial basis only. This is because Article I of the Outer Space Treaty refers to the free use, free access of outer space and its celestial bodies. There is nothing in Article I that implicitly refers to the use and access of space technology. Thus, the trading of remote sensing data could not be contrary to the common interest principle in the Outer Space Treaty, because it falls beyond the scope of this provision, in my opinion.

Regarding the equitable sharing benefit encompassed in the Common Heritage principle, there are divergent views as to its meaning. One school of thought assumes that the reluctance of space-faring nations to ratify the Moon Agreement is attributable to the fact that these states believe that this rule could (or would) be interpreted in favor of developing states i.e., the benefit derived from space resources must be shared equally among all states regardless of their individual contributions. Thus, space-power nations are unwilling to share the benefits from their labor and investment and insist that such sharing does not apply to the technology in the exploration.

Notwithstanding how equitable sharing should be interpreted, this provision is not applicable to remote sensing data. This is because the

112 UN General Assembly Resolution 41/65, 3 December 1986, namely, 'Principles on Remote Sensing of the Earth from Space', A/RES/41/65 (hereinafter UN Remote Sensing Principles). Available online at <http://www. unoosa.org/pdf/gares/ARES_41_65E.pdf> (accessed 31 January 2016).

113 Ethiopia v. S.Africa; Liberia v. S.Africa (Second Phase) [1966] ICJ Rep 6 at 50-51, para 98, see also Reijnen (n 108) 90.

114 Ibid 91. 
Common Heritage principle of Article 11(1) of the Moon Agreement, and the exploration and use of the Moon based on equality as stated in Article 11(4), clearly relate to exploitation of the Moon itself and its resources. Nothing in these provisions refers to exploitation of technology. In addition, the remote sensing data represents data about the earth, not the Moon. Thus, I believe that remote sensing data falls outside the scope of the Province and the Common Heritage principles. In addition, refusing the sensing state an opportunity to obtain a return from its investment would lessen the incentive for those states to develop space technology. This would hinder all states from reaping any indirect benefit of this technological advantage.

As regards satellite telecommunication, similar reference is needed to UN Resolution 37/92 which relates to direct broadcasting satellites. Principle A of this resolution states that direct broadcasting satellites 'should promote the free dissemination and mutual exchange of information and knowledge in cultural and scientific field', and Principle C indicates that 'all states and people are entitled to and should enjoy the benefits from such activities. Access to the technology in this field should be available to all states without discrimination on terms mutually agreed by all concerned'. ${ }^{115}$ As a result of this resolution, some scholars believe that the commercial practice of state involvement in direct broadcasting satellites would impede the equal sharing rules as enunciated in space treaties, interpreting this UN resolution in the same way as that relating of remote sensing. ${ }^{116}$

Nevertheless, I believe that neither the freedom of use, freedom of access nor the equal sharing benefit refers to satellite technology for the same reasons discussed in connection with remote sensing. In addition, the condition that access to the technology will be subject to 'mutual agreement' does not preclude an exchange of information on a commercial basis. Thus, I would conclude that the operation of satellite communication in outer space is not opposed to those space law doctrines. In addition, it is necessary to keep in mind that this resolution is not legally binding and only covers direct broadcasting satellites, not all satellite telecommunication.

115 UN General Assembly Resolution 37/92, 10 December 1982, 'Principles Governing the Use by States of Artificial Earth Satellites for International Direct Television Broadcasting', A/RES/37/92 (hereafter UN Direct Broadcasting Satellites Principle) <http://www.unoosa.org/pdf/gares/ARES_37_92E.pdf> (accessed 31 January 2016).

116 Reijnen (n 108) 92. 
But I draw different conclusions in the case of space-created activities as compared with those in the space-related activities. This is because the former engages in the 'utilization' of space resources both physically (in case of Helium-3) or indirectly (in case of the production of goods under zero gravity). Therefore, it is more likely and justifiable to interpret that all benefits deriving from these particular space activities must be shared equally among states to comply the conditions set forth in space treaties. But as mentioned earlier, allowing all states to access and share benefits from the exploitative activities, without reasonably rewarding the owner of these technology in return, would definitely hinder the development of space technology. As a result of generally reducing the incentives for space investment, this in turn would hamper dissemination of those particular benefits from those space activities which should be available to all mankind.

\section{CONCLUSION}

In conclusion, none of the principles in the space treaties as discussed explicitly refer to the relinquishment of intellectual property rights in outer space. On the contrary, these rules should be interpreted in the way to support and allow an increase in commercial activities in outer space, because the benefit deriving from the exploitation and use of outer space is without doubt of great advantage and importance for human kind.

The next chapter will focus on the international conventions relating to intellectual property rights, and it will investigate how and to what extent such rights are relevant to outer space activities. 